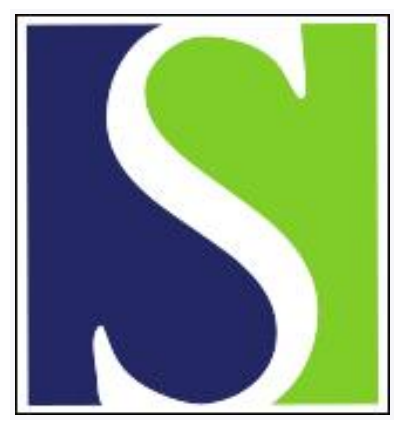

Scand J Work Environ Health 2007;33(4):304-317

https://doi.org/10.5271/sjweh.1147

Issue date: 31 Aug 2007

Population-based study on occupational risk factors for preeclampsia and gestational hypertension

by Haelterman E, Marcoux S, Croteau A, Dramaix M

Affiliation: Département de Biostatistiques, Ecole de Santé Publique, Université Libre de Bruxelles; Campus Erasme, CP 597; Route de Lennik, 808; B-1070 Bruxelles; Belgium. ehaelter@ulb.ac.be

Refers to the following texts of the Journal: 1998;24(5):334-343 1998;24(3):206-212

The following articles refer to this text: 2018;44(4):403-413;

2021;47(1):33-41; 2022;48(3):239-247

Key terms: employment; exertion; gestational hypertension; job strain; job stress; occupational health; occupational physical activity; occupational risk factor; population-based study; posture; preeclampsia; pregnancy outcome; pregnancy-induced hypertension

This article in PubMed: www.ncbi.nlm.nih.gov/pubmed/17717623 


\title{
Population-based study on occupational risk factors for preeclampsia and gestational hypertension
}

\author{
by Edwige Haelterman, MSc, ${ }^{1,2}$ Sylvie Marcoux, PhD, ${ }^{1}$ Agathe Croteau, PhD, ${ }^{3}$ Michèle Dramaix, PhD ${ }^{2}$
}

\begin{abstract}
Haelterman E, Marcoux S, Croteau A, Dramaix M. Population-based study on occupational risk factors for preeclampsia and gestational hypertension. Scand J Work Environ Health 2007;33(4):304-317.

Objectives Preeclampsia is a leading cause of maternal and perinatal morbidity. Work-related factors may influence the occurrence of this disorder. This case-control study estimated the associations between work-related physical and psychosocial factors and the risk of preeclampsia and gestational hypertension.

Methods The eligible women consisted of a random sample of the women who delivered a singleton live birth in 1997-1999 in six regions of Quebec and worked during pregnancy. Cases of preeclampsia $(\mathrm{N}=102)$ and gestational hypertension ( $\mathrm{N}=99$ ) were compared with normotensive controls $(\mathrm{N}=4381)$. Information on occupational exposures at the onset of pregnancy was collected during phone interviews a few weeks after delivery. Detailed information was obtained on work schedule, postures, physical exertion, work organization, noise, vibration, and extreme temperature. Adjusted odds ratios (aOR) were estimated through polytomous logistic regression.

Results Women standing daily at least 1 hour consecutively without walking experienced a higher risk of preeclampsia [aOR 2.5, 95\% confidence interval (95\% CI) 1.4-4.6], as well as women climbing stairs frequently (aOR 2.3, 95\% CI 1.2-4.1) and women working more than 5 consecutive days without a day-off (aOR 3.0, 95\% CI 1.0-9.5). Squatting or kneeling, pushing or pulling objects, whole-body vibration, forced pace, job strain, and no control on breaks were positively, but nonsignificantly, associated with preeclampsia. The associations were weaker for gestational hypertension.
\end{abstract}

Conclusions These findings suggest that being exposed to physically demanding and stressful occupational conditions at the onset of pregnancy increases the risk of preeclampsia.

Key terms employment; exertion; job strain; job stress; occupational health; occupational physical activity; posture; population-based study; pregnancy outcome; pregnancy-induced hypertension.

Preeclampsia, defined as the development of hypertension with proteinuria after 20 weeks of pregnancy, is one of the most common causes of maternal adverse outcome and death and a major contributor to perinatal morbidity and mortality (1-4). By contrast, the mild form of pregnancy-induced hypertension, gestational hypertension, does not significantly affect the mother or the neonate $(4,5)$.

Working during pregnancy was found to be associated with an increased frequency of preeclampsia (6-9) and gestational hypertension (8) in some studies. In other studies, however, such an association was not found (10-14).
Supported by solid literature relating job stress to cardiovascular diseases (15-17), three studies investigated the relation of job stress to pregnancy-induced hypertension $(7,8,18)$. They showed fairly consistent evidence of an association between high job stress and an increased risk of gestational hypertension and preeclampsia.

A high level of physical activity at work was found to be associated with an elevated risk of preeclampsia (11) or hypertension in pregnancy $(19,20)$ in a few studies (table 1). In particular, women who carry heavy loads at work experienced an approximately $70 \%$ increase in the occurrence of preeclampsia (10) and hypertension

1 Département de médecine sociale et préventive, Faculté de médecine, Université Laval (Department of Social and Preventive Medicine, Faculty of Medicine, Laval University), Quebec, Canada.

Département de Biostatistiques, École de Santé Publique, Université Libre de Bruxelles (Biostatistics Department, School of Public Health, Free University of Brussels), Brussels, Belgium.

Institut national de santé publique du Québec et Direction de santé publique de Québec (Quebec National Institute of Public Health and Quebec Regional Public Health Direction), Canada.

Reprint requests to: Edwige Haelterman; Département de Biostatistiques, Ecole de Santé Publique, Université Libre de Bruxelles; Campus Erasme, CP 597; Route de Lennik, 808; B-1070 Bruxelles; Belgium. [E-mail: ehaelter@ulb.ac.be] 
Table 1. Methodological characteristics and main results of the studies that examined associations of occupational physical activity with gestational hypertension and preeclampsia in pregnant working women. (BMI = body mass index)

\begin{tabular}{|c|c|c|c|c|c|c|c|c|c|c|}
\hline \multirow[t]{2}{*}{ Study } & \multirow[t]{2}{*}{ Design } & \multirow{2}{*}{$\begin{array}{l}\text { Data } \\
\text { collection }\end{array}$} & \multirow{2}{*}{$\begin{array}{l}\text { Sample size } \\
\text { and outcome }\end{array}$} & \multirow[t]{2}{*}{ Exposure definition } & \multirow{2}{*}{$\begin{array}{l}\text { Period } \\
\text { of ex- } \\
\text { posure }\end{array}$} & \multirow{2}{*}{$\begin{array}{l}\text { Adjust- } \\
\text { ment for } \\
\text { potential } \\
\text { confound- } \\
\text { ers }\end{array}$} & \multicolumn{4}{|c|}{ Result } \\
\hline & & & & & & & $\begin{array}{l}\text { Carrying } \\
\text { heavy loads }\end{array}$ & $\begin{array}{l}\text { Standing or } \\
\text { walking }\end{array}$ & $\begin{array}{l}\text { Summary mea- } \\
\text { sure of physical } \\
\text { exertion }\end{array}$ & Other \\
\hline $\begin{array}{l}\text { Saurel- } \\
\text { Cubi- } \\
\text { zolles } \\
\text { et al, } \\
1985 \\
(19) \text {; } \\
\text { Saurel- } \\
\text { Cubi- } \\
\text { zolles } \\
\text { et al, } \\
1991 \\
(20)\end{array}$ & $\begin{array}{l}\text { Retro- } \\
\text { spec- } \\
\text { tive } \\
\text { cohort } \\
\end{array}$ & $\begin{array}{l}\text { Interview } \\
\text { when re- } \\
\text { suming } \\
\text { work }\end{array}$ & $\begin{array}{l}621 \text { women; } \\
\text { outcome was } \\
\text { self-reported } \\
\text { systolic blood } \\
\text { pressure }>130 \\
\mathrm{mmHg} \text { or di- } \\
\text { astolic blood } \\
\text { pressure } \\
>80 \mathrm{mmHg} \\
\text { any time dur- } \\
\text { ing pregnancy } \\
(\mathrm{N}=90)\end{array}$ & Yes, no & $\begin{array}{l}\text { Not } \\
\text { provid- } \\
\text { ed }\end{array}$ & $\begin{array}{l}\text { Age, parity, } \\
\text { father so- } \\
\text { cioprofes- } \\
\text { sional lev- } \\
\text { el, ethnic } \\
\text { origin }\end{array}$ & $\begin{array}{l}\text { Carrying } \\
\text { heavy loads } \\
\text { associat- } \\
\text { ed with } \\
\text { high blood } \\
\text { pressure }\end{array}$ & $\begin{array}{l}\text { Standing up for } \\
\text { long periods of } \\
\text { time associated } \\
\text { with high blood } \\
\text { pressure }\end{array}$ & $\begin{array}{l}\text { Accumulation } \\
\text { of heavy clean- } \\
\text { ing tasks, carry- } \\
\text { ing heavy loads, } \\
\text { and standing up } \\
\text { for long periods } \\
\text { of time associ- } \\
\text { ated with high } \\
\text { blood pressure } \\
\text { (OR 3.3, 95\% Cl } \\
2.0-5.5)\end{array}$ & $\begin{array}{l}\text { Climbing stairs } \\
\text { often not as- } \\
\text { sociated with } \\
\text { high blood } \\
\text { pressure }\end{array}$ \\
\hline $\begin{array}{l}\text { Estryn } \\
\text { et al, } \\
1978 \\
(21)\end{array}$ & $\begin{array}{l}\text { Retro- } \\
\text { spec- } \\
\text { tive } \\
\text { cohort }\end{array}$ & $\begin{array}{l}\text { Interview } \\
\text { when re- } \\
\text { suming } \\
\text { work }\end{array}$ & $\begin{array}{l}204 \text { women, } \\
\text { among whom } \\
26 \text { with self- } \\
\text { reported hy- } \\
\text { pertension } \\
\text { (not defined) } \\
\text { any time dur- } \\
\text { ing pregnancy }\end{array}$ & Yes, no & $\begin{array}{l}\text { Not } \\
\text { provid- } \\
\text { ed }\end{array}$ & None & $\begin{array}{l}\text { Carrying } \\
\text { heavy loads } \\
\text { increased risk } \\
\text { of hyperten- } \\
\text { sion }(17 \% \\
\text { versus } 6 \%)\end{array}$ & $\begin{array}{l}\text { Standing up for } \\
\text { long periods of } \\
\text { time not associ- } \\
\text { ated with hyper- } \\
\text { tension; standing } \\
\text { up without mov- } \\
\text { ing increased risk } \\
\text { (18\% versus } 8 \% \text { ) }\end{array}$ & - & - \\
\hline $\begin{array}{l}\text { Saurel- } \\
\text { Cubi- } \\
\text { zolles } \\
\text { et al, } \\
1991 \\
(22)\end{array}$ & $\begin{array}{l}\text { Retro- } \\
\text { spec- } \\
\text { tive } \\
\text { cohort }\end{array}$ & $\begin{array}{l}\text { Interview } \\
\text { after } \\
\text { delivery }\end{array}$ & $\begin{array}{l}2587 \text { women; } \\
\text { outcome was } \\
\text { self-reported } \\
\text { systolic blood } \\
\text { pressure } \\
\geq 140 \mathrm{mmHg} \\
\text { or diastol- } \\
\text { ic blood } \\
\text { pressure } \\
\geq 90 \text { mmHg } \\
\text { any time dur- } \\
\text { ing pregnancy } \\
\text { ( } \mathrm{N}=285 \text { ) }\end{array}$ & $\begin{array}{l}\text { Yes, no; physical ex- } \\
\text { ertion not defined }\end{array}$ & $\begin{array}{l}\text { First } \\
\text { trimes- } \\
\text { ter }\end{array}$ & $\begin{array}{l}\text { Other work } \\
\text { conditions, } \\
\text { parity, age, } \\
\text { level of ed- } \\
\text { ucation, } \\
\text { smoking, } \\
\text { BMI }\end{array}$ & $\begin{array}{l}\text { Carrying } \\
\text { heavy loads } \\
\text { associated } \\
\text { with third tri- } \\
\text { mester high } \\
\text { blood pres- } \\
\text { sure (OR 1.7, } \\
95 \% \text { Cl 1.2-- } \\
2.4 \text { ) but not } \\
\text { with first } \\
\text { and sec- } \\
\text { ond trimes- } \\
\text { ter high blood } \\
\text { pressure }\end{array}$ & $\begin{array}{l}\text { Standing most } \\
\text { of the time } \\
\text { not associated } \\
\text { with high blood } \\
\text { pressure }\end{array}$ & $\begin{array}{l}\text { Strong phys- } \\
\text { ical exertion } \\
\text { not associated } \\
\text { with high blood } \\
\text { pressure }\end{array}$ & - \\
\hline $\begin{array}{l}\text { Nurmi- } \\
\text { nen } \\
\text { et al, } \\
1989 \\
(24)\end{array}$ & $\begin{array}{l}\text { Retro- } \\
\text { spec- } \\
\text { tive } \\
\text { cohort }\end{array}$ & $\begin{array}{l}\text { Interview } \\
2-4 \\
\text { months } \\
\text { after de- } \\
\text { livery and } \\
\text { medi- } \\
\text { cal record } \\
\text { abstraction }\end{array}$ & $\begin{array}{l}1475 \text { women, } \\
\text { among whom } \\
59 \text { with preg- } \\
\text { nancy-induced } \\
\text { hypertension }\end{array}$ & $\begin{array}{l}\text { Physical load as- } \\
\text { sessed from a de- } \\
\text { scription of tasks } \\
\text { during an ordi- } \\
\text { nary workday and } \\
\text { translated in energy } \\
\text { expenditure }\end{array}$ & $\begin{array}{l}\text { Second } \\
\text { and } \\
\text { third } \\
\text { trimes- } \\
\text { ters }\end{array}$ & $\begin{array}{l}\text { Age, pari- } \\
\text { ty, outcome } \\
\text { of previous } \\
\text { pregnan- } \\
\text { cies, pre- } \\
\text { pregnan- } \\
\text { cy weight, } \\
\text { alcohol in- } \\
\text { take, and } \\
\text { smoking }\end{array}$ & - & $\begin{array}{l}\text { Standing work } \\
\text { and walking } \\
\text { work not associ- } \\
\text { ated with preg- } \\
\text { nancy-induced } \\
\text { hypertension }\end{array}$ & $\begin{array}{l}\text { High mean } \\
\text { physical load } \\
\text { not associat- } \\
\text { ed with preg- } \\
\text { nancy-induced } \\
\text { hypertension }\end{array}$ & $\begin{array}{l}\text { High short- } \\
\text { term physical } \\
\text { load associated } \\
\text { with pregnan- } \\
\text { cy-induced hy- } \\
\text { pertension (RR } \\
2.1,95 \% \mathrm{Cl} \\
1.1-3.8)\end{array}$ \\
\hline $\begin{array}{l}\text { Mar- } \\
\text { coux } \\
\text { et al, } \\
1989 \\
(26)\end{array}$ & $\begin{array}{l}\text { Case- } \\
\text { con- } \\
\text { trol }\end{array}$ & $\begin{array}{l}\text { Interview } \\
\text { at the hos- } \\
\text { pital a few } \\
\text { days after } \\
\text { delivery } \\
\text { and medi- } \\
\text { cal record } \\
\text { abstraction }\end{array}$ & $\begin{array}{l}254 \text { cas- } \\
\text { es of gesta- } \\
\text { tional hyper- } \\
\text { tension, } 172 \\
\text { cases of pre- } \\
\text { eclampsia and } \\
505 \text { controls }\end{array}$ & $\begin{array}{l}\text { Walking (frequent } \\
\text { versus not fre- } \\
\text { quent) and stand- } \\
\text { ing position (hours/ } \\
\text { day) during a regular } \\
\text { workday }\end{array}$ & $\begin{array}{l}\text { First } 20 \\
\text { weeks }\end{array}$ & $\begin{array}{l}\text { Restricted } \\
\text { to primip- } \\
\text { arous; age, } \\
\text { BMI, ed- } \\
\text { ucation; } \\
\text { smoking, } \\
\text { and leisure- } \\
\text { time phys- } \\
\text { ical activ- } \\
\text { it taken into } \\
\text { account }\end{array}$ & - & $\begin{array}{l}\text { Standing position } \\
\text { not associated } \\
\text { with preeclamp- } \\
\text { sia or gestational } \\
\text { hypertension; fre- } \\
\text { quent walking } \\
\text { associated with } \\
\text { a reduced risk } \\
\text { of preeclampsia } \\
\text { (OR 0.6, 95\% Cl } \\
0.4-0.9) \text { but } \\
\text { not gestational } \\
\text { hypertension }\end{array}$ & - & - \\
\hline $\begin{array}{l}\text { Lands- } \\
\text { ber- } \\
\text { gis \& } \\
\text { Hatch, } \\
1996 \\
\text { (8) }\end{array}$ & $\begin{array}{l}\text { Pro- } \\
\text { spec- } \\
\text { tive } \\
\text { cohort }\end{array}$ & $\begin{array}{l}\text { Interview } \\
\text { by phone } \\
\text { around } \\
13 \text { weeks } \\
\text { of gesta- } \\
\text { tion and } \\
\text { medi- } \\
\text { cal record } \\
\text { abstraction }\end{array}$ & $\begin{array}{l}575 \text { women } \\
\text { among which } \\
11 \text { with pre- } \\
\text { eclampsia } \\
\text { and } 16 \text { with } \\
\text { gestational } \\
\text { hypertension }\end{array}$ & $\begin{array}{l}\text { Physical work de- } \\
\text { mands measured } \\
\text { as the sum of five } \\
\text { items: (1) climbing } \\
\text { or balancing, (2) lift- } \\
\text { ing, carrying, pulling } \\
\text { or pushing objects, } \\
\text { (3) moving around a } \\
\text { lot, (4) exerting a lot } \\
\text { of physical effort, (5) } \\
\text { sitting or standing in } \\
\text { uncomfortable posi- } \\
\text { tions for long peri- } \\
\text { ods of time }\end{array}$ & $\begin{array}{l}\text { First } \\
\text { trimes- } \\
\text { ter }\end{array}$ & $\begin{array}{l}\text { None (main } \\
\text { objec- } \\
\text { tive was } \\
\text { to study } \\
\text { impact } \\
\text { of work } \\
\text { stress) }\end{array}$ & & - & $\begin{array}{l}\text { High physical } \\
\text { work demand } \\
\text { not associated } \\
\text { with preeclamp- } \\
\text { sia or gestation- } \\
\text { al hypertension }\end{array}$ & (continued) \\
\hline
\end{tabular}


Table 1. Continued.

\begin{tabular}{|c|c|c|c|c|c|c|c|c|c|c|}
\hline \multirow[t]{2}{*}{ Study } & \multirow[t]{2}{*}{ Design } & \multirow{2}{*}{$\begin{array}{l}\text { Data } \\
\text { collection }\end{array}$} & \multirow{2}{*}{$\begin{array}{l}\text { Sample size } \\
\text { and outcome }\end{array}$} & \multirow[t]{2}{*}{ Exposure definition } & \multirow{2}{*}{$\begin{array}{l}\text { Period } \\
\text { of ex- } \\
\text { posure }\end{array}$} & \multirow{2}{*}{$\begin{array}{l}\text { Adjust- } \\
\text { ment for } \\
\text { potential } \\
\text { confound- } \\
\text { ers }\end{array}$} & \multicolumn{4}{|c|}{ Result } \\
\hline & & & & & & & $\begin{array}{l}\text { Carrying } \\
\text { heavy loads }\end{array}$ & $\begin{array}{l}\text { Standing or } \\
\text { walking }\end{array}$ & $\begin{array}{l}\text { Summary mea- } \\
\text { sure of physical } \\
\text { exertion }\end{array}$ & Other \\
\hline $\begin{array}{l}\text { Irwin } \\
\text { et al, } \\
1994 \\
(25)\end{array}$ & $\begin{array}{l}\text { Retro- } \\
\text { spec- } \\
\text { tive } \\
\text { cohort }\end{array}$ & $\begin{array}{l}\text { Job types } \\
\text { assessed } \\
\text { from a } \\
\text { routine } \\
\text { database } \\
\text { and hos- } \\
\text { pital dis- } \\
\text { charge } \\
\text { record } \\
\text { abstraction }\end{array}$ & $\begin{array}{l}5605 \text { wom- } \\
\text { en, outcome } \\
\text { was pregnan- } \\
\text { cy-induced } \\
\text { hypertension } \\
\text { (ICD-9 diag- } \\
\text { nosis codes) } \\
\text { (N=494) }\end{array}$ & $\begin{array}{l}\text { Job titles classi- } \\
\text { fied as high, medi- } \\
\text { um, or low for a va- } \\
\text { riety of occupational } \\
\text { exposures }\end{array}$ & $\begin{array}{l}\text { Not } \\
\text { provid- } \\
\text { ed }\end{array}$ & $\begin{array}{l}\text { No adjust- } \\
\text { ment; anal- } \\
\text { yses strati- } \\
\text { fied for par- } \\
\text { ity (primip- } \\
\text { arous ver- } \\
\text { sus multip- } \\
\text { arous) }\end{array}$ & $\begin{array}{l}\text { Jobs with } \\
\text { high level of } \\
\text { lifting not as- } \\
\text { sociated with } \\
\text { pregnan- } \\
\text { cy-induced } \\
\text { hypertension }\end{array}$ & $\begin{array}{l}\text { Jobs with high } \\
\text { level of stand- } \\
\text { ing associated } \\
\text { with pregnancy- } \\
\text { induced hyper- } \\
\text { tension (RR 1.5, } \\
95 \% \mathrm{Cl} 1.0-2.5 \text { ) } \\
\text { only in multipa- } \\
\text { rous women }\end{array}$ & $\begin{array}{l}\text { Jobs with high } \\
\text { level of phys- } \\
\text { ical exertion } \\
\text { not associat- } \\
\text { ed with preg- } \\
\text { nancy-induced } \\
\text { hypertension }\end{array}$ & - \\
\hline $\begin{array}{l}\text { Werge- } \\
\text { land \& } \\
\text { Strand, } \\
1997 \\
(10)\end{array}$ & $\begin{array}{l}\text { Retro- } \\
\text { spec- } \\
\text { tive } \\
\text { cohort }\end{array}$ & $\begin{array}{l}\text { Question- } \\
\text { naire com- } \\
\text { pleted by } \\
\text { mothers } \\
\text { after deliv- } \\
\text { ery, while } \\
\text { in the ma- } \\
\text { ternity } \\
\text { institution }\end{array}$ & $\begin{array}{l}3321 \text { wom- } \\
\text { en among } \\
\text { whom } 180 \\
\text { with self-re- } \\
\text { ported hyper- } \\
\text { tension and } \\
\text { proteinuria }\end{array}$ & $\begin{array}{l}\text { Questions with 3-5 } \\
\text { response categories; } \\
\text { lifting heavy loads } \\
\text { defined as lifting 10- } \\
20 \text { kg more than } 20 \\
\text { times weekly; daily } \\
\text { frequency for other } \\
\text { exposure }\end{array}$ & $\begin{array}{l}\text { When } \\
\text { be- } \\
\text { came } \\
\text { aware } \\
\text { of } \\
\text { preg- } \\
\text { nancy }\end{array}$ & $\begin{array}{l}\text { Smoking, } \\
\text { other oc- } \\
\text { cupation- } \\
\text { al expo- } \\
\text { sures, age, } \\
\text { instruc- } \\
\text { tion level, } \\
\text { and parity } \\
\text { taken into } \\
\text { account }\end{array}$ & $\begin{array}{l}\text { Lifting heavy } \\
\text { loads asso- } \\
\text { ciated with } \\
\text { preeclamp- } \\
\text { sia (OR 1.7, } \\
95 \% \mathrm{Cl} \\
1.2-2.5)\end{array}$ & $\begin{array}{l}\text { Standing or walk- } \\
\text { ing associat- } \\
\text { ed with a slight- } \\
\text { ly reduced risk } \\
\text { of preeclampsia } \\
(0 \mathrm{R} 0.7,95 \% \mathrm{Cl} \\
0.5-1.0)\end{array}$ & & $\begin{array}{l}\text { Work with } \\
\text { hands above } \\
\text { shoulder level } \\
\text { associated with } \\
\text { preeclamp- } \\
\text { sia (OR 1.4, } \\
95 \% \mathrm{Cl} 1.0- \\
\text { 2.2), twisting } \\
\text { or bending not } \\
\text { associated with } \\
\text { preeclampsia }\end{array}$ \\
\hline $\begin{array}{l}\text { Ceron- } \\
\text { Mireles } \\
\text { et al, } \\
2001 \\
(23)\end{array}$ & $\begin{array}{l}\text { Retro- } \\
\text { spec- } \\
\text { tive } \\
\text { cohort }\end{array}$ & $\begin{array}{l}\text { Interview } \\
\text { in the hos- } \\
\text { pital after } \\
\text { delivery } \\
\text { and medi- } \\
\text { cal record } \\
\text { abstraction }\end{array}$ & $\begin{array}{l}2436 \text { women } \\
\text { among whom } \\
131 \text { with pre- } \\
\text { eclampsia or } \\
\text { eclampsia }\end{array}$ & $\begin{array}{l}\text { Job requiring phys- } \\
\text { ical effort (yes, no); } \\
\text { standing (hours/day) }\end{array}$ & $\begin{array}{l}\text { Not } \\
\text { provid- } \\
\text { ed }\end{array}$ & $\begin{array}{l}\text { Parity, } \\
\text { age, pre- } \\
\text { pregnan- } \\
\text { cy weight, } \\
\text { smoking, } \\
\text { and edu- } \\
\text { cation tak- } \\
\text { en into } \\
\text { account }\end{array}$ & - & $\begin{array}{l}\text { Standing not as- } \\
\text { sociated with } \\
\text { preeclampsia }\end{array}$ & $\begin{array}{l}\text { Work physical } \\
\text { effort not as- } \\
\text { sociated with } \\
\text { preeclampsia }\end{array}$ & - \\
\hline $\begin{array}{l}\text { Spinillo } \\
\text { et al, } \\
1995 \\
(11)\end{array}$ & $\begin{array}{l}\text { Case- } \\
\text { con- } \\
\text { trol }\end{array}$ & $\begin{array}{l}\text { Question- } \\
\text { naire ad- } \\
\text { ministered } \\
\text { at birth } \\
\text { and medi- } \\
\text { cal record } \\
\text { abstraction }\end{array}$ & $\begin{array}{l}122 \text { cases of } \\
\text { severe pre- } \\
\text { eclampsia and } \\
217 \text { controls }\end{array}$ & $\begin{array}{l}\text { Four-level score } \\
\text { of physical activi- } \\
\text { ty including items on } \\
\text { type of work, physi- } \\
\text { cal intensity (seden- } \\
\text { tary, moderate or in- } \\
\text { tense), posture, and } \\
\text { workhours }\end{array}$ & $\begin{array}{l}\text { First } \\
\text { trimes- } \\
\text { ter }\end{array}$ & $\begin{array}{l}\text { Adjustment } \\
\text { made for } \\
\text { age, so- } \\
\text { cial status, } \\
\text { BMI, time } \\
\text { of stop- } \\
\text { ping work, } \\
\text { and history } \\
\text { of previous } \\
\text { abortion }\end{array}$ & & 更 & $\begin{array}{l}\text { Moderate or } \\
\text { high level of } \\
\text { physical activity } \\
\text { associated with } \\
\text { preeclampsia } \\
(0 \mathrm{R} 2.1,95 \% \mathrm{Cl} \\
1.1-3.9)\end{array}$ & - \\
\hline $\begin{array}{l}\text { Hig- } \\
\text { gins } \\
\text { et al, } \\
2002 \\
(29)\end{array}$ & $\begin{array}{l}\text { Pro- } \\
\text { spec- } \\
\text { tive } \\
\text { cohort }\end{array}$ & $\begin{array}{l}\text { Interview } \\
\text { during } \\
\text { pregnan- } \\
\text { cy, medi- } \\
\text { cal record } \\
\text { abstrac- } \\
\text { tion, 24- } \\
\text { hour am- } \\
\text { bulato- } \\
\text { ry blood } \\
\text { pressure } \\
\text { monitoring }\end{array}$ & $\begin{array}{l}245 \text { wom- } \\
\text { en, outcome } \\
\text { was gesta- } \\
\text { tional hyper- } \\
\text { tension and } \\
\text { preeclamp- } \\
\text { sia, and } \\
\text { mean blood } \\
\text { pressure }\end{array}$ & $\begin{array}{l}\text { Job titles classified } \\
\text { into three categories: } \\
\text { (1) standing, (2) ac- } \\
\text { tive, (3) sedentary }\end{array}$ & $\begin{array}{l}\text { Not } \\
\text { provid- } \\
\text { ed }\end{array}$ & $\begin{array}{l}\text { Age, smok- } \\
\text { ing, BMI, } \\
\text { and marital } \\
\text { status }\end{array}$ & & $\begin{array}{l}\text { Standing jobs not } \\
\text { associated with } \\
\text { gestational hy- } \\
\text { pertension or } \\
\text { preclampsia }\end{array}$ & $\begin{array}{l}\text { Active jobs not } \\
\text { associated with } \\
\text { preeclampsia } \\
\text { or gestational } \\
\text { hypertension; } \\
\text { higher mean 24- } \\
\text { hour diastol- } \\
\text { ic blood pres- } \\
\text { sure for women } \\
\text { with active job } \\
\text { compared with } \\
\text { women with } \\
\text { sedentary jobs } \\
\text { (65.6 versus } \\
63.4 \mathrm{mmHg})\end{array}$ & - \\
\hline $\begin{array}{l}\text { Saftlas } \\
\text { et al, } \\
2004 \\
(27)\end{array}$ & $\begin{array}{l}\text { Case- } \\
\text { control } \\
\text { with } \\
\text { pro- } \\
\text { spec- } \\
\text { tive da- } \\
\text { ta col- } \\
\text { lection }\end{array}$ & $\begin{array}{l}\text { Face-to- } \\
\text { face inter- } \\
\text { views be- } \\
\text { fore } 16 \\
\text { weeks of } \\
\text { gestation } \\
\text { and review } \\
\text { of medical } \\
\text { charts }\end{array}$ & $\begin{array}{l}44 \text { cases of } \\
\text { preeclamp- } \\
\text { sia, } 172 \text { cases } \\
\text { of gestational } \\
\text { hypertension, } \\
\text { and } 2422 \\
\text { controls }\end{array}$ & $\begin{array}{l}\text { Time at work spent } \\
\text { sitting, standing } \\
\text { and walking; wom- } \\
\text { en with sedentary } \\
\text { work (more time sit- } \\
\text { ting than standing) } \\
\text { versus nonseden- } \\
\text { tary work (more time } \\
\text { walking or standing } \\
\text { than sitting); propor- } \\
\text { tion of time spent } \\
\text { sitting (three levels) }\end{array}$ & $\begin{array}{l}\text { Early } \\
\text { preg- } \\
\text { nan- } \\
\text { cy }(<16 \\
\text { weeks } \\
\text { of ges- } \\
\text { tation) } \\
\end{array}$ & $\begin{array}{l}\text { Adjustment } \\
\text { for age, } \\
\text { parity, his- } \\
6 \text { tory of } \\
\text { abortion, } \\
\text { BMI, years } \\
\text { of educa- } \\
\text { tion, ciga- } \\
\text { rette smok- } \\
\text { ing, and lei- } \\
\text { sure-time } \\
\text { physical ac- } \\
\text { tivity tak- } \\
\text { en into } \\
\text { account }\end{array}$ & & $\begin{array}{l}\text { Non- } \\
\text { significantly re- } \\
\text { duced risk of pre- } \\
\text { eclampsia in non- } \\
\text { sedentary jobs } \\
\text { and in the low } \\
\text { or moderate sit- } \\
\text { ting categories; } \\
\text { gestational hy- } \\
\text { pertension not } \\
\text { associated }\end{array}$ & - & - \\
\hline
\end{tabular}


during pregnancy (19-22) in four studies. However, these few studies have been challenged by others showing that a high physical workload does not confer an increased risk of preeclampsia (23) or pregnancy-induced hypertension $(8,24,25)$. They are also in contrast to those suggesting that leisure-time physical activity may reduce the risk of preeclampsia (26-28).

A few studies have assessed the association of pregnancy-induced hypertension with other occupational exposures such as standing-up, keeping back bent forward, keeping arms above shoulders, or twisting and bending for long periods of time $(10,19-27,29)$, noise $(10,22$, $23,30)$, or long weekly workhours $(10,19,20,22,23$, $31)$. These studies provide conflicting results.

In summary, diverse occupational conditions may be associated with a higher risk of pregnancy-induced hypertension. However, the literature on this issue is scanty, and findings from previous studies are highly inconsistent and conflicting. These studies often lacked statistical power and relied on poor exposure or outcome definitions (table 1). Either no exposure definition was provided or no mention of period or the amount of exposure was made. Outcome was defined as hypertension at any time during pregnancy in several studies, and, for those that used pregnancy-induced hypertension as the outcome, preeclampsia was often not distinguished from gestational hypertension. The data analysis usually presented several shortcomings. Typically, no attempt was made to examine dose-response effects, and control for potential confounders was inadequate. In particular, only two studies proceeded to adjustments for other occupational exposures $(10,22)$. Currently, a vast proportion of pregnant women work during pregnancy, therefore the need for studies addressing the limitations of previous studies. We conducted this case-control study in order to estimate the associations of occupational physical exertion and postures, work schedule, job strain, breaks during worktime, workpace, noise, whole-body vibration, and extreme temperature with the risk of preeclampsia and gestational hypertension.

\section{Study population and methods}

\section{Study population}

We were authorized by the "Commission d'accès à l'information du Québec" to obtain personal data recorded on birth certificates for all singleton live births between January 1997 and March 1999 in six regions of the Province of Quebec (Saguenay-Lac-Saint-Jean, Québec, Mauricie-Centre-du-Québec, Estrie, ChaudièreAppalaches, Laval). A total of 43898 singleton live births was reported to the investigators by the Regional Public Health Directions (93.7\% of the singleton live births declared). The source population for our present case-control study was a random sample of $20 \%$ $(\mathrm{N}=8902)$ of the women who delivered these singleton live births. This sample was drawn in the context of a previous study (32).

The interviewers were able to make telephone contact with $8411(94.5 \%)$ potential participants. Of those contacted, 8267 (98.3\%) agreed to participate. Only the women who had been employed since the first month of pregnancy, during at least 4 consecutive weeks and at least 20 hours weekly were eligible ( $\mathrm{N}=4959)$. Those who had several employments during pregnancy were excluded $(\mathrm{N}=196)$. Altogether 4763 women who completed the interview were left. For our present analysis, we excluded 27 women who declared a history of hypertension or diabetes requiring medication before pregnancy and 7 others with a chronic disease that can predispose to preeclampsia (rheumatoid arthritis, ulcerative colitis, systemic lupus erythematosus).

During the interview, each woman had to report whether she experienced preeclampsia. She was also asked about blood pressure equal to or over 140/90 $\mathrm{mmHg}$ and proteinuria or albuminuria during pregnancy, including timing and number of episodes. In order to reduce the risk of outcome misclassification, we also excluded 147 women who experienced hypertension before 20 weeks of gestation or who reported only one episode of hypertension or who declared having had preeclampsia in the index pregnancy but did not report two episodes of hypertension or proteinuria from the 20th week of gestation on.

The cases with preeclampsia were comprised of women who had two self-reported episodes of elevated blood pressure $(\geq 140 / 90 \mathrm{mmHg})$ with self-reported albuminuria both first occurring in the 20th week of gestation on $(\mathrm{N}=102)$. The cases with gestational hypertension were comprised of women who reported an elevation of blood pressure on at least two occasions occurring from the 20th week of gestation on without albuminuria ( $\mathrm{N}=99)$. Thus, of the 4582 women with no chronic disease predisposing to preeclampsia, delivery of a singleton live birth, work during pregnancy, and interview completion, $2.2 \%$ was classified as cases of preeclampsia and $2.2 \%$ as cases of gestational hypertension. The controls $(\mathrm{N}=4381)$ were all of the remaining eligible women (ie, women who remained normotensive during pregnancy).

\section{Data collection}

Exposures and covariates were ascertained through a standardized computerized telephone interview (median time of interview: 31 days postpartum for preeclampsia, 28 days for gestational hypertension, and 30 days for the controls). Detailed information was collected on work 
schedule, postures, physical exertion, breaks, workpace, job strain (Karaseks' model) $(33,34)$, social support, and environmental exposures (noise, vibration, temperature) at the onset of pregnancy (see the appendix). The women reported time spent sitting, standing, and walking during a typical workday. The daily frequency of pushing or pulling objects, carrying or lifting loads, and stair climbing during a typical workday was asked for. The average weight carried or lifted was reported. The women were also asked whether they benefited from a preventive withdrawal or from job reassignment. Notification of the withdrawal or reassignment timing was required. In Quebec, pregnant women whose work conditions are considered to entail a risk for themselves or their fetuses can legally benefit from job reassignment or, if not possible, can be withdrawn from work on salary. Last, data were obtained on medical and obstetrical history, type of delivery, leisure-time physical activity, smoking, pregravid weight, height, and level of education. In addition to the women's identification data, age, birth weight, gestational duration, and parity were obtained from the birth certificate.

\section{Analysis}

Occupational exposures were defined from information on work conditions at the onset of pregnancy. [See the appendix.] The number of hours worked per day and during evenings or nights was computed from the work schedule. The variables were examined separately and then combined (eg, time spent standing crossed with possibility to sit, average weight of load carried crossed with frequency of load carrying, opportunity to have a break with control on the time of the break). The job psychological demand score (sum of nine items) and the job control score (sum of nine items) were both dichotomized at the median for the controls. Job strain was defined by combining job demand and job control into the following four levels: low demand-high control, low demand-low control, high demand-high control, and high demand-low control.

The following set of covariates was used in all of the adjusted analyses: age ( $<25$ years, $25-29$ years, $30-34$ years, $>34$ years), parity (primiparous versus multiparous), history of abortion (spontaneous or induced) (yes, no), body mass index $\left(<25.0 \mathrm{~kg} / \mathrm{m}^{2}, 25.0-29.9 \mathrm{~kg} / \mathrm{m}^{2}\right.$, $\geq 30.0 \mathrm{~kg} / \mathrm{m}^{2}$ ), smoking during the last 3 months of pregnancy (no smoking versus smoking at least 1 cigarette per day), education (in three levels), and leisure-time physical activity during the first trimester of pregnancy (less than once a month, once a month-twice a week, 3 times per week or more).

We first computed crude odds ratios (OR) for the associations between occupational exposures at the onset of pregnancy and the outcomes. We combined the categories with small numbers and similar odds ratios. We then estimated adjusted odds ratios (aOR) using polytomous logistic regression (SAS, CATMOD procedure) (35). Occupational exposures were first examined one-by-one, with adjustment for the aforementioned set of covariates. At the next step, we analyzed each subset of occupational variables belonging to the same group (schedule, postures, physical exertion, work organization and job strain, environmental exposures). Using multiple logistic regressions, we examined the effect of each occupational exposure with adjustment not only for the aforementioned set of covariates, but also for the potentially confounding effect of other occupational exposures of the same group. To avoid collinearity, when two variables were highly correlated, we only kept the one most strongly related to the outcomes for further analyses. The 11 occupational variables that remained associated with the outcomes at this step were then considered simultaneously in a model. At each step of our analysis, the models were simplified by keeping occupational exposures associated with the outcomes $(\mathrm{aOR} \geq 1.20$ or $\leq 0.80)$ for further analyses. Other occupational variables were deleted if deletion did not change the adjusted odds ratios for the other exposures. Ultimately, nine occupational variables remained in the final model.

We tested interactions between weekly workhours, job strain, and the number of consecutive days of work without a day-off on one hand and the other occupational variables in the final model on the other hand. To assess preventive withdrawal, we then compared the women exposed for less than 20 weeks (those who utilized preventive withdrawal before 20 weeks of gestation) with the unexposed women.

Ultimately, we verified the robustness of our findings by comparing the adjusted odds ratios from our final model with the adjusted odds ratios obtained when selfreported preeclampsia was used as the outcome.

To assess dose-response relationships for variables with more than two ordered categories, we used the linear component of the polynomial contrast corresponding to the variable. All along the analyses, we examined standard errors of the regression coefficients and variance inflation factors to check for collinearity. The analyses were performed with SAS (SAS Inc, Gary, NC, USA) and SPSS (SPSS Inc, Chicago, IL, USA) software.

\section{Results}

The outcome of pregnancy differed for the three groups (table 2). The mean birthweight was 256 grams lower for the babies of the women who had had preeclampsia 
Table 2. Comparison of pregnancy outcomes among the cases and controls.

\begin{tabular}{|c|c|c|c|c|c|c|c|c|c|c|c|c|}
\hline \multirow[t]{3}{*}{ Group } & \multicolumn{12}{|c|}{ Pregnancy outcome } \\
\hline & \multicolumn{2}{|c|}{$\begin{array}{l}\text { Elective cesarean } \\
\text { section }(\%)\end{array}$} & \multicolumn{2}{|c|}{$\begin{array}{l}\text { Labor induction } \\
(\%)\end{array}$} & \multicolumn{2}{|c|}{$\begin{array}{c}\text { Gestational age at } \\
\text { birth }<37 \text { weeks }(\%)\end{array}$} & \multicolumn{2}{|c|}{$\begin{array}{l}\text { Birthweight } \\
<2500 \mathrm{~g}(\%)\end{array}$} & \multicolumn{2}{|c|}{$\begin{array}{l}\text { Gestational age } \\
\text { at birth (week) }\end{array}$} & \multicolumn{2}{|c|}{$\begin{array}{l}\text { Birthweigh } \\
\text { (grams) }\end{array}$} \\
\hline & $\mathrm{N}$ & $\%$ & $\mathrm{~N}$ & $\%$ & $\mathrm{~N}$ & $\%$ & $\mathrm{~N}$ & $\%$ & Mean & SD & Mean & SD \\
\hline Controls ( $N=4381)$ & 245 & 5.6 & 990 & 22.6 & 216 & 4.9 & 143 & 3.3 & 39.1 & 1.6 & 3411 & 501 \\
\hline Preeclampsia $(\mathrm{N}=102)$ & 8 & 7.9 & 66 & 65.3 & 15 & 14.7 & 15 & 14.7 & 38.2 & 2.0 & 3155 & 693 \\
\hline Gestational hypertension (N=99) & 7 & 7.1 & 44 & 44.4 & 2 & 2.0 & 4 & 4.0 & 39.0 & 1.4 & 3390 & 488 \\
\hline
\end{tabular}

Table 3. Distribution of maternal sociodemographic, reproductive, and lifestyle baseline characteristics among the cases and controls. $(\mathrm{OR}=$ odds ratio, $95 \% \mathrm{Cl}=95 \%$ confidence interval)

\begin{tabular}{|c|c|c|c|c|c|c|c|c|c|c|}
\hline \multirow[t]{2}{*}{ Maternal characteristics } & \multicolumn{2}{|c|}{$\begin{array}{l}\text { Controls } \\
(\mathrm{N}=4381)\end{array}$} & \multicolumn{2}{|c|}{$\begin{array}{l}\text { Preeclampsia } \\
\quad(\mathrm{N}=102)\end{array}$} & \multicolumn{2}{|c|}{$\begin{array}{l}\text { Gestational hyper- } \\
\text { tension }(\mathrm{N}=99)\end{array}$} & \multicolumn{2}{|c|}{ Preeclampsia } & \multicolumn{2}{|c|}{$\begin{array}{c}\text { Gestational } \\
\text { hypertension }\end{array}$} \\
\hline & $\mathrm{N}$ & $\%$ & $\mathrm{~N}$ & $\%$ & $\mathrm{~N}$ & $\%$ & Crude OR & $95 \% \mathrm{Cl}$ & Crude OR & R $95 \% \mathrm{Cl}$ \\
\hline \multicolumn{11}{|l|}{ Age } \\
\hline $\begin{array}{l}\leq 24 \text { years } \\
30-3425-29 \text { years } \\
30-34 \text { years } \\
\geq 35 \text { years }\end{array}$ & $\begin{array}{r}795 \\
1732 \\
1386 \\
468\end{array}$ & $\begin{array}{l}18.2 \\
39.5 \\
31.6 \\
10.7\end{array}$ & $\begin{array}{l}23 \\
32 \\
34 \\
13\end{array}$ & $\begin{array}{l}22.6 \\
31.4 \\
33.3 \\
12.7\end{array}$ & $\begin{array}{l}24 \\
26 \\
30 \\
19\end{array}$ & $\begin{array}{l}24.2 \\
26.3 \\
30.3 \\
19.2\end{array}$ & $\begin{array}{l}1.6 \\
1.0 \\
1.3 \\
1.5\end{array}$ & $\begin{array}{c}0.9-2.7 \\
. \cdot \\
0.8-2.2 \\
0.8-2.9\end{array}$ & $\begin{array}{l}2.0 \\
1.0 \\
1.4 \\
2.7\end{array}$ & $\begin{array}{c}1.2-3.5 \\
\quad \cdot \\
0.9-2.5 \\
1.5-4.9\end{array}$ \\
\hline \multicolumn{11}{|c|}{ Parity and history of spontaneous or induced abortion } \\
\hline $\begin{array}{l}\text { Multiparous without history of abortion } \\
\text { Primiparous without history of abortion } \\
\text { Multiparous with a history of abortion } \\
\text { Primiparous with a history of abortion }\end{array}$ & $\begin{array}{r}1682 \\
1784 \\
539 \\
376\end{array}$ & $\begin{array}{r}38.4 \\
40.7 \\
12.3 \\
8.6\end{array}$ & $\begin{array}{l}25 \\
47 \\
10 \\
20\end{array}$ & $\begin{array}{r}24.5 \\
46.1 \\
9.8 \\
19.6\end{array}$ & $\begin{array}{l}24 \\
50 \\
11 \\
14\end{array}$ & $\begin{array}{l}24.2 \\
50.5 \\
11.1 \\
14.1\end{array}$ & $\begin{array}{l}1.0 \\
1.8 \\
1.3 \\
3.6\end{array}$ & $\begin{array}{l}\cdot \ddot{1} \\
1.1-2.9 \\
0.6-2.6 \\
2.0-6.5\end{array}$ & $\begin{array}{l}1.0 \\
2.0 \\
1.4 \\
2.6\end{array}$ & $\begin{array}{l}. \ddot{ } \\
1.2-3.2 \\
0.7-2.9 \\
1.3-5.1\end{array}$ \\
\hline \multicolumn{11}{|l|}{ Level of education } \\
\hline $\begin{array}{l}<12 \text { years } \\
12-16 \text { years } \\
\geq 17 \text { years }\end{array}$ & $\begin{array}{r}315 \\
2760 \\
1298\end{array}$ & $\begin{array}{r}7.2 \\
63.1 \\
29.7\end{array}$ & $\begin{array}{r}8 \\
68 \\
26\end{array}$ & $\begin{array}{r}7.8 \\
66.7 \\
25.5\end{array}$ & $\begin{array}{l}10 \\
65 \\
24\end{array}$ & $\begin{array}{l}10.1 \\
65.7 \\
24.2\end{array}$ & $\begin{array}{l}1.3 \\
1.2 \\
1.0\end{array}$ & $\begin{array}{l}0.6-2.8 \\
0.8-1.9 \\
\quad . \cdot\end{array}$ & $\begin{array}{l}1.7 \\
1.3 \\
1.0\end{array}$ & $\begin{array}{c}0.8-3.6 \\
0.8-2.0 \\
\quad . .\end{array}$ \\
\hline Smoking during the last trimester of pregnancy & 831 & 19.0 & 11 & 10.8 & 13 & 13.1 & 0.5 & $0.3-1.0$ & 0.6 & $0.4-1.2$ \\
\hline \multicolumn{11}{|l|}{ Body mass index } \\
\hline $\begin{array}{l}<25.0 \mathrm{~kg} / \mathrm{m}^{2} \\
25.0-29.9 \mathrm{~kg} / \mathrm{m}^{2} \\
\geq 30 \mathrm{~kg} / \mathrm{m}^{2}\end{array}$ & $\begin{array}{r}3409 \\
678 \\
279\end{array}$ & $\begin{array}{r}78.1 \\
15.5 \\
6.4\end{array}$ & $\begin{array}{l}52 \\
32 \\
18\end{array}$ & $\begin{array}{l}51.0 \\
31.4 \\
17.6\end{array}$ & $\begin{array}{l}52 \\
30 \\
17\end{array}$ & $\begin{array}{l}52.5 \\
30.3 \\
17.2\end{array}$ & $\begin{array}{l}1.0 \\
3.1 \\
4.2\end{array}$ & $\begin{array}{c}\ddot{*} \\
2.0-4.8 \\
2.4-7.3\end{array}$ & $\begin{array}{l}1.0 \\
2.9 \\
4.0\end{array}$ & $\begin{array}{c}\cdot . \\
1.8-4.6 \\
2.3-7.0\end{array}$ \\
\hline \multicolumn{11}{|c|}{ Vigorous leisure-time physical activity during the first trimester of pregnancy } \\
\hline $\begin{array}{l}\text { Less than once/month } \\
\text { Once/month-twice/week } \\
\text { More than twice/week }\end{array}$ & $\begin{array}{r}3499 \\
540 \\
333\end{array}$ & $\begin{array}{r}80.0 \\
12.4 \\
7.6\end{array}$ & $\begin{array}{l}79 \\
12 \\
11\end{array}$ & $\begin{array}{l}77.4 \\
11.8 \\
10.8\end{array}$ & $\begin{array}{l}72 \\
15 \\
12\end{array}$ & $\begin{array}{l}72.7 \\
15.2 \\
12.1\end{array}$ & $\begin{array}{l}1.0 \\
1.0 \\
1.5\end{array}$ & $\begin{array}{c}0.6-1.9 \\
\quad \cdot \\
0.6-3.4\end{array}$ & $\begin{array}{l}0.7 \\
1.0 \\
1.3\end{array}$ & $\begin{array}{c}0.4-1.3 \\
\quad . \\
0.6-2.8\end{array}$ \\
\hline
\end{tabular}

than for the babies of the control women. In contrast, the babies of the women with gestational hypertension averaged only 21 grams lighter than the babies of the control women. The risk of low birthweight and preterm birth was strongly increased in the group with preeclampsia but not in the group with gestational hypertension. As compared with the controls, the women with preeclampsia and those with gestational hypertension had labor induction three times and twice more frequently, respectively. The frequency of elective prelabor cesarean section was slightly and nonsignificantly increased in the two case groups.

Table 3 shows the distribution of the maternal characteristics among the cases and the controls. The women who had had preeclampsia or gestational hypertension were more likely to have been primiparous, were more frequently either in the younger ( $\leq 24$ years) or older ( $\geq 30$ years) age category, and were less likely to be smokers. They showed an increase in the frequency of overweight and an even stronger increase in the frequency of obesity.

We then estimated the adjusted odds ratios for the associations of occupational exposures with preeclampsia and gestational hypertension. Table 4 shows a first series of odds ratios adjusted for the common set of classical covariates (age, parity, history of abortion, body mass index, smoking, education, and leisure-time physical activity). The second series of odds ratios in the last two columns of table 4 have been adjusted for the common set of covariates, as well as for the other occupational exposures with an adjusted odds ratio in the corresponding column. Only occupational exposures with an 
Table 4. Associations between occupational risk factors at the onset of pregnancy and the risks of preeclampsia and gestational hypertension. $(95 \% \mathrm{Cl}=95 \%$ confidence intervals)

\begin{tabular}{|c|c|c|c|c|c|c|c|c|c|c|c|}
\hline \multirow{2}{*}{$\begin{array}{l}\text { Occupational } \\
\text { exposure }\end{array}$} & \multirow{2}{*}{$\begin{array}{c}\text { Controls } \\
(\mathrm{N}=4381) \\
(\mathrm{N})\end{array}$} & \multirow{2}{*}{$\begin{array}{c}\text { Preeclamp- } \\
\text { sia }(N=102) \\
(N)\end{array}$} & \multirow{2}{*}{$\begin{array}{l}\text { Gestation- } \\
\text { al hyperten- } \\
\text { sion }(N=99) \\
(N)\end{array}$} & \multicolumn{2}{|c|}{ Preeclampsia } & \multicolumn{2}{|c|}{ Gestational hypertension } & \multicolumn{2}{|c|}{ Preeclampsia } & \multicolumn{2}{|c|}{ Gestational hypertension } \\
\hline & & & & $\mathrm{OR}^{\mathrm{a}}$ & $95 \% \mathrm{Cl}^{\mathrm{a}}$ & $\mathrm{OR}^{\mathrm{a}}$ & $95 \% \mathrm{Cl}^{\mathrm{a}}$ & $\mathrm{OR}^{\mathrm{b}}$ & $95 \% \mathrm{Cl}^{\mathrm{b}}$ & $\mathrm{OR}^{\mathrm{b}}$ & $95 \% \mathrm{Cl}^{\mathrm{b}}$ \\
\hline
\end{tabular}

Work schedule

Average number of weekly workhours

\begin{tabular}{|c|c|c|c|c|c|c|c|c|c|c|c|}
\hline $20-34$ & 1303 & 27 & 26 & 1.0 & .. & 1.0 & .. & . & . & . & . \\
\hline $35-40$ & 2658 & 64 & 63 & 1.2 & $0.7-1.8$ & 1.2 & $0.7-1.9$ & . & . & . & . \\
\hline$>40$ & 420 & 11 & 10 & 1.2 & $0.6-2.5$ & 1.1 & $0.5-2.4$ & . & . & . & . \\
\hline \multicolumn{12}{|c|}{ Workhours varying from week to week } \\
\hline No & 3467 & 76 & 76 & 1.0 & .. & 1.0 & .. & . & . & . & . \\
\hline Yes & 914 & 26 & 23 & 1.2 & $0.8-1.9$ & 1.1 & $0.7-1.8$ & . & . & . & . \\
\hline \multicolumn{12}{|c|}{ Typical consecutive number of days without a day off } \\
\hline $1-3$ & 463 & 6 & 7 & 1.0 & .. & 1.0 & .. & 1.0 & .. & 1.0 & .. \\
\hline $4-5$ & 3659 & 86 & 85 & 1.7 & $0.7-4.0$ & 1.4 & $0.7-3.1$ & 1.6 & $0.7-3.8$ & 1.5 & $0.7-3.3$ \\
\hline $6-12$ & 194 & 7 & 5 & 2.6 & $0.8-7.9$ & 1.6 & $0.5-5.1$ & 3.0 & $1.0-9.5$ & 1.8 & $0.5-5.8$ \\
\hline \multicolumn{12}{|c|}{ Average number of weekly evening workhours (0600 to 2300) } \\
\hline None & 2776 & 62 & 66 & 1.0 & .. & 1.0 & .. & . & . & . & . \\
\hline $1-6$ & 838 & 19 & 19 & 1.0 & $0.6-1.7$ & 0.9 & $0.6-1.6$ & . & . & $\cdot$ & . \\
\hline $7-32$ & 747 & 19 & 12 & 1.1 & $0.7-1.9$ & 0.7 & $0.4-1.3$ & . & . & . & . \\
\hline \multicolumn{12}{|c|}{ Average number of weekly night workhours (2300 to 0600) } \\
\hline None & 3888 & 89 & 86 & 1.0 & .. & 1.0 & .. & - & . & . & . \\
\hline$\geq 1$ & 473 & 11 & 11 & 1.0 & $0.5-2.0$ & 1.0 & $0.5-2.0$ & . & . & . & . \\
\hline
\end{tabular}

Work postures

Number of hours spent walking c

$\begin{array}{lrrrrrrc}<2 & 1882 & 43 & 47 & 1.0 & 0.5-1.8 & 1.5 & 0.8-2.9 \\ 2 \text { to }<3 & 676 & 15 & 11 & 1.0 & . . & 1.0 & . . \\ \geq 3 & 1806 & 44 & 41 & 1.0 & 0.6-1.9 & 1.3 & 0.7-2.6\end{array}$

Number of consecutive hours spent standing at the same place, without walking ${ }^{c}$

\begin{tabular}{|c|c|c|c|c|c|c|c|c|c|c|c|}
\hline 0 & 2694 & 48 & 65 & 1.0 & .. & 1.0 & .. & 1.0 & .. & 1.0 & .. \\
\hline$>0$ to $<1$ & 1237 & 32 & 25 & 1.4 & $0.9-2.2$ & 0.8 & $0.5-1.3$ & 1.3 & $0.8-2.1$ & 0.7 & $0.4-1.2$ \\
\hline$\geq 1$ & 404 & 21 & 8 & 2.9 & $1.7-5.0$ & 0.7 & $0.4-1.6$ & 2.5 & $1.4-4.6$ & 0.7 & $0.3-1.6$ \\
\hline \multicolumn{12}{|c|}{ Number of hours spent squatting or kneeling ${ }^{c}$} \\
\hline 0 & 3031 & 63 & 71 & 1.0 & $\cdot \cdot$ & 1.0 & .. & 1.0 & .. & 1.0 & .. \\
\hline$>0$ to $<1$ & 875 & 22 & 13 & 1.2 & $0.7-2.0$ & 0.6 & $0.3-1.2$ & 1.2 & $0.7-2.0$ & 0.5 & $0.3-1.0$ \\
\hline$\geq 1$ & 429 & 17 & 15 & 1.8 & $1.0-3.1$ & 1.4 & $0.8-2.6$ & 1.5 & $0.8-2.7$ & 1.1 & $0.6-2.2$ \\
\hline
\end{tabular}

Number of hours spent with arms above shoulder level c

$\begin{array}{lrrrrrrr}0 & 2902 & 68 & 63 & 1.0 & . . & 1.0 & . . \\ >0 \text { to }<1 & 481 & 8 & 9 & 0.7 & 0.3-1.5 & 0.9 & 0.4-1.8 \\ \geq 1 & 941 & 26 & 26 & 1.1 & 0.7-1.8 & 1.2 & 0.7-1.9\end{array}$

Number of hours spent with back bent forward ${ }^{d}$

$\begin{array}{lrllllll}0 & 2509 & 50 & 60 & 1.0 & . . & 1.0 & . . \\ >0 \text { to }<1 & 837 & 27 & 12 & 1.7 & 1.0-2.7 & 0.6 & 0.3-1.2 \\ \geq 1 & 972 & 25 & 27 & 1.2 & 0.7-2.0 & 1.1 & 0.7-1.7\end{array}$

Occupational physical exertion

Carrying or lifting loads ${ }^{d}$

\begin{tabular}{|c|c|c|c|c|c|c|c|c|c|c|c|}
\hline \multicolumn{12}{|c|}{ valiying of inting ivaus } \\
\hline Never & 2283 & 48 & 47 & 1.0 & $\cdot$. & 1.0 &.$\cdot$ & . & . & . & . \\
\hline $\begin{array}{l}\text { Weight } 1-6 \mathrm{~kg} \\
\text { or frequency }\end{array}$ & & & & & & & & & & & \\
\hline $\begin{array}{l}1-9 \text { times/day } \\
\text { Weight } \geq 7 \mathrm{~kg} \\
\text { and frequency } \\
\geq 10 \text { times }\end{array}$ & 1644 & 39 & 38 & 1.1 & $0.7-1.7$ & 1.1 & $0.7-1.7$ & . & $\cdot$ & · & $\cdot$ \\
\hline per day & 429 & 14 & 14 & 1.4 & $0.7-2.5$ & 1.3 & $0.7-2.5$ & . & . & . & . \\
\hline \multicolumn{12}{|c|}{ Pushing or pulling objects or persons ${ }^{c}$} \\
\hline Never & 2915 & 58 & 59 & 1.0 & .. & 1.0 & .. & 1.0 &.$\cdot$ & 1.0 & .. \\
\hline$<5$ times per day & 533 & 12 & 9 & 1.1 & $0.6-2.1$ & 0.8 & $0.4-1.6$ & 0.9 & $0.5-1.8$ & 0.9 & $0.5-2.0$ \\
\hline$\geq 5$ times per day & 929 & 31 & 31 & 1.6 & $1.0-2.5$ & 1.6 & $1.0-2.5$ & 1.2 & $0.7-2.1$ & 1.9 & $1.1-3.1$ \\
\hline \multicolumn{12}{|c|}{ Climbing stairs ${ }^{d}$ (daily frequency) } \\
\hline Never & 2275 & 40 & 57 & 1.0 & .. & 1.0 & .. & 1.0 & $\cdots$ & 1.0 & .. \\
\hline $1-4$ & 956 & 24 & 20 & 1.5 & $0.9-2.6$ & 0.9 & $0.5-1.5$ & 1.7 & $1.0-2.9$ & 0.8 & $0.5-1.4$ \\
\hline $5-9$ & 554 & 21 & 8 & 2.5 & $1.4-4.3$ & 0.7 & $0.3-1.4$ & 2.3 & $1.2-4.1$ & 0.6 & $0.3-1.3$ \\
\hline$\geq 10$ & 589 & 17 & 14 & 1.9 & $1.0-3.3$ & 1.1 & $0.6-2.0$ & 1.9 & $1.0-3.5$ & 0.9 & $0.5-1.8$ \\
\hline
\end{tabular}


Table 4. Continued.

\begin{tabular}{|c|c|c|c|c|c|c|c|c|c|c|c|}
\hline \multirow{2}{*}{$\begin{array}{l}\text { Occupational } \\
\text { exposure }\end{array}$} & \multirow{2}{*}{$\begin{array}{l}\text { Controls } \\
(\mathrm{N}=4381) \\
(\mathrm{N})\end{array}$} & \multirow{2}{*}{$\begin{array}{l}\text { Preeclamp- } \\
\text { sia }(N=102) \\
(N)\end{array}$} & \multirow{2}{*}{$\begin{array}{c}\text { Gestation- } \\
\text { al hyperten- } \\
\text { sion }(N=99) \\
(N)\end{array}$} & \multicolumn{2}{|c|}{ Preeclampsia } & \multicolumn{2}{|c|}{ Gestational hypertension } & \multicolumn{2}{|c|}{ Preeclampsia } & \multicolumn{2}{|c|}{ Gestational hypertension } \\
\hline & & & & $O R^{a}$ & $95 \% \mathrm{Cl}^{\mathrm{a}}$ & $O R^{a}$ & $95 \% \mathrm{Cl}^{\mathrm{a}}$ & $\mathrm{OR}^{\mathrm{b}}$ & $95 \% \mathrm{Cl}^{\mathrm{b}}$ & $\mathrm{OR}^{\mathrm{b}}$ & $95 \% \mathrm{Cl}^{\mathrm{b}}$ \\
\hline \multicolumn{12}{|c|}{ Work environment exposures } \\
\hline \multicolumn{12}{|c|}{ Noisy environment ${ }^{d}$} \\
\hline No & 3725 & 87 & 85 & 1.0 &.. & 1.0 &.. & . & . & . & . \\
\hline Yes & 655 & 15 & 14 & 0.9 & $0.5-1.6$ & 0.9 & $0.5-1.6$ & . & . & . & . \\
\hline \multicolumn{12}{|c|}{ Extreme temperatures ${ }^{e}$} \\
\hline Never or rarely & 3792 & 80 & 80 & 1.0 & .. & 1.0 & $\cdot$. & . & . & . & . \\
\hline $\begin{array}{l}\text { Frequently or } \\
\text { always }\end{array}$ & 589 & 22 & 19 & 1.6 & $1.0-2.6$ & 1.3 & $0.8-2.2$ & . & . & . & . \\
\hline \multicolumn{12}{|c|}{ Whole-body vibration (any exposure) } \\
\hline No & 4070 & 92 & 91 & 1.0 & .. & 1.0 & .. & 1.0 & .. & 1.0 & .. \\
\hline Yes & 305 & 10 & 8 & 1.4 & $0.7-2.8$ & 1.1 & $0.5-2.2$ & 1.2 & $0.6-2.5$ & 0.9 & $0.4-2.2$ \\
\hline \multicolumn{12}{|c|}{ Work organization and job strain } \\
\hline \multicolumn{12}{|c|}{ Break during half-day work ${ }^{c}$} \\
\hline \multicolumn{12}{|c|}{$\begin{array}{l}\text { Always or most } \\
\text { often and oppor- } \\
\text { tunity to choose }\end{array}$} \\
\hline \multicolumn{12}{|l|}{$\begin{array}{l}\text { Always or most } \\
\text { often but no } \\
\text { opportunity to }\end{array}$} \\
\hline choose the time & 1194 & 33 & 27 & 1.8 & $1.0-3.2$ & 1.1 & $0.6-1.9$ & 1.3 & $0.7-2.5$ & 1.0 & $0.6-1.9$ \\
\hline Never or rarely & 1894 & 46 & 43 & 1.7 & $1.0-2.9$ & 1.2 & $0.7-2.0$ & 1.5 & $0.9-2.7$ & 1.2 & $0.7-2.1$ \\
\hline \multicolumn{12}{|c|}{ Forced pace, piece work or assembly-line work } \\
\hline No & 4081 & 91 & 90 & 1.0 & .. & 1.0 & .. & 1.0 & .. & 1.0 & .. \\
\hline Yes & 292 & 11 & 9 & 1.6 & $0.8-3.1$ & 1.1 & $0.5-2.4$ & 1.5 & $0.7-3.4$ & 0.9 & $0.4-2.1$ \\
\hline \multicolumn{12}{|c|}{ Job strain according to Karasek's model } \\
\hline \multirow{4}{*}{$\begin{array}{l}\text { Low demand- } \\
\text { high latitude } \\
\text { Low demand- } \\
\text { low latitude } \\
\text { High demand- } \\
\text { high latitude } \\
\text { High demand- } \\
\text { low latitude }\end{array}$} & 973 & 14 & 25 & 1.0 & .. & 1.0 &.. & 1.0 &.. & 1.0 &.$\cdot$ \\
\hline & 1129 & 24 & 23 & 1.4 & $0.7-2.7$ & 0.7 & $0.4-1.3$ & 1.3 & $0.6-2.7$ & 0.7 & $0.4-1.4$ \\
\hline & 1175 & 29 & 19 & 1.8 & $0.9-3.4$ & 0.6 & $0.4-1.2$ & 1.7 & $0.8-3.2$ & 0.6 & $0.3-1.1$ \\
\hline & 1067 & 33 & 32 & 2.1 & $1.1-3.9$ & 1.1 & $0.6-1.9$ & 1.7 & $0.8-3.3$ & 1.0 & $0.6-1.9$ \\
\hline
\end{tabular}

a Adjusted for age, parity, history of abortion, level of education, body mass index, smoking, leisure-time physical activity.

${ }^{b}$ Adjusted for age, parity, history of abortion, level of education, body mass index, smoking, leisure-time physical activity, and the other occupational exposures with an odds ratio in this column of the table.

${ }^{c}$ Average number during a typical workday.

${ }^{d}$ Usually, to be heard by someone at 2 meters: could speak normally (not exposed), had to speak loudly or shout (exposed).

${ }^{\mathrm{e}}$ High temperature producing sweating in most people or low temperature obliging people to wear a coat.

adjusted odds ratio equal to or above 1.20 or equal to below 0.80 were kept in this latter analysis.

Most of the occupational variables examined showed odds ratios between 1.00 and 1.20 (nonsignificant) for the association with preeclampsia, whether in the crude or adjusted analyses. The associations with gestational hypertension were usually even weaker. Most of the adjusted associations were slightly weaker than the corresponding crude ones.

\section{Work schedule}

The average number of weekly workhours and other characteristics of the work schedule, such as working during evening or night, were similarly distributed among the cases and controls. The number of consecutive workdays without a day off was strongly associated with preeclampsia. The adjusted odds ratio for preeclampsia was 3.0 for 6-12 days when compared with the value for less than 4 days, and a dose-response relation was observed (test for trend, $\mathrm{P}=0.064$ ). Such increased risk was also found for gestational hypertension, but the corresponding odds ratios were lower.

\section{Work postures}

Spending time walking did not influence the risk of preeclampsia or gestational hypertension. In contrast, spending time standing without walking was related to a higher risk of preeclampsia, and this association showed a dose-response relation (test for trend, $\mathrm{P}=0.003$ ). The women who spent consecutively at least 1 hour daily in such a posture experienced a particularly increased risk of preeclampsia (aOR 2.5). There was no such 
association with gestational hypertension. The influence of squatting or kneeling on the risk of preeclampsia was moderate and nonsignificant. Spending time with arms above the shoulders was not associated with the outcomes.

\section{Occupational physical exertion}

Carrying or lifting loads of at least 7 kilograms at least 10 times a day was related to an increased risk for preeclampsia before other occupational exposures were taken into account (aOR 1.4). However, after other occupational exposures were introduced into the regression model, carrying or lifting loads was not associated with a higher risk for either outcome $(\mathrm{aOR}<1.2)$. In contrast, pushing or pulling objects or persons at least five times a day was slightly associated with preeclampsia (aOR 1.2) and more strongly in relation to gestational hypertension (aOR 1.9). The women who climbed stairs had approximately twice the odds of experiencing preeclampsia as compared with the women who never did. No regular increase in the adjusted odds ratio with level of exposure was observed. Climbing stairs was not related to gestational hypertension.

\section{Work environment exposures}

Whole-body vibration slightly increased the risk of preeclampsia (aOR 1.2), but this association was not significant. Noise and extreme temperatures were not associated with the outcomes.

\section{Job strain and workbreaks}

The women who never or rarely had a workbreak, those who had no control of the time of their breaks, and those working with a forced pace or in piecework or on an assembly line tended to experience an increased risk of preeclampsia. The adjusted odds ratio for preeclampsia was 1.7 (nonsignificant) for the women with high job strain (high demand-low latitude) when they were compared with those with low job strain (low demand-high latitude). Social support by colleagues and by superiors did not modify the association (not shown). In contrast, job strain did not increase the risk of gestational hypertension.

There was no interaction between weekly workhours, job strain, and the number of consecutive days of work without a day off on one hand and the other occupational variables on the other.

Preventive withdrawals were frequently used. Nearly half of the preventive withdrawals occurred before 20 weeks of gestation. Of the control women, $17.7 \%$ benefited from a preventive withdrawal before 20 gestational weeks (21.6\% of preeclamptic women and $24.2 \%$ of the women with gestational hypertension). Another $8.7 \%$ of the control women used preventive reassignments or personal arrangements with employers instead of preventive withdrawal before 20 weeks $(9.8 \%$ of the women with preeclampsia and $8.1 \%$ of the women with gestational hypertension). The adjusted odds ratios for preeclampsia were similar whether the exposed women benefited from a preventive withdrawal before 20 weeks of pregnancy or remained exposed for a longer period.

Except for workbreaks, the associations had a similar magnitude when self-reported preeclampsia was used as the outcome instead of self-reported hypertension plus proteinuria in our final model. No association was found between control of the time of workbreak and self-reported preeclampsia.

\section{Discussion}

This study suggests that physically demanding occupational conditions (such as pushing or pulling objects or persons, climbing stairs) and strenuous postures (such as standing for long periods without walking, squatting or kneeling) at the onset of pregnancy increase the risk of preeclampsia. Job strain, forced pace, no breaktime or no control of breaktime, and a high number of consecutive workdays were also related to a higher risk of preeclampsia, although statistical significance was not achieved for some of these exposures.

On the whole, the literature on the impact of occupational physical activity on pregnancy-induced hypertension is sparse, the methods used are poorly described, and findings are inconsistent (table 1). Most of the previous studies had insufficient power to detect associations with preeclampsia, did not distinguish between preeclampsia and gestational hypertension, used very imprecise definitions of physical activity, did not control for the confounding effect of other occupational exposures, and did not take account of the level of exposure. We were able to assess dose-response effects, as we quantified the amount of exposure. This was not the case in several previous studies in which very crude yes or no questions were used to assess physical activity at work (table 1). In addition, our study took several occupational exposures into account in the analyses simultaneously, and only two previous studies have followed the same procedure $(10,22)$. Most previous studies did not distinguish between preeclampsia and gestational hypertension, or even between hypertension and pregnancy-induced hypertension (table 1). In contrast, we analyzed preeclampsia and gestational hypertension separately. This approach was critical because it is still unknown whether the two entities have a common 
etiology and because misclassification with essential hypertension may be more frequent for gestational hypertension than for preeclampsia. The weaker patterns of associations found for gestational hypertension in this study are consistent with gestational hypertension being a mix of mild forms of preeclampsia and of misclassified latent essential hypertension. Although power was not outstanding in our study, it was better than for most earlier studies. Several of them had a very small number of preeclampsia cases. Only one included more women than our study did (25), and only 4 of 12 included more cases of preeclampsia $(10,11,23,26)$. Of these four studies, none fully adjusted for other occupational exposures as we did.

Among the limited number of studies that assessed the impact of physical activity on the risk of pregnancyinduced hypertension, the ways to measure physical activity varied a great deal. Some used yes or no questions about physical activities at work, while others used composite measures of physical exertion, such scores based on job titles $(25,29)$ or based on summing yes or no items (8). Ways to combine exposures in order to define physical exertion were not standardized. The use of disparate definitions of physical activity at work certainly accounts for inconsistencies among the findings.

Four studies used a composite measure of occupational physical activity during pregnancy in relation to preeclampsia $(8,11,23)$, gestational hypertension (8), or pregnancy-induced hypertension (24). Nurminen et al (24) built a score for physical workload reflecting energy expenditure from the description of worktasks. Spinillo et al (11) combined physical intensity (not defined), posture, and number of workhours. Landsbergis \& Hatch (8) estimated physical work demands as the sum of a person's responses to five items (climbing or balancing, lifting or carrying, pulling or pushing objects, moving around a lot, exerting physical effort, sitting or standing in uncomfortable positions for long periods). In a last report, no definition of physical activity at work was provided (23). Of these four studies, only one reported a positive association (11).

Few studies have considered specific aspects of physical activity at work separately, as in our study. A limited number of exposures was usually examined, and the exposure levels were often not reported. Only two studies $(10,26)$ are comparable with ours in the way to define exposures. They assessed the effect of several aspects of physical activity on preeclampsia separately and quantified the level of exposure. Only one of them examined a large number of exposures related to physical activity at work as we did. This study also suggested that physical exertion and strenuous postures during pregnancy increase the risk of preeclampsia (10).

Carrying heavy loads was found to be associated with hypertension (19-22) or preeclampsia (10) in four studies. In our study, carrying heavy loads was no longer associated with preeclampsia $(\mathrm{OR}<1.2)$ once other occupational exertion, such as pushing or pulling objects, was taken into account. This contrast with previous studies may reflect a low level of exposure to carrying heavy loads in this population.

In two French studies, prolonged standing was related to a higher risk of hypertension during pregnancy (19-21). This finding contrasts with those of other studies in which prolonged standing was associated with a decreased $(10)$ or unchanged $(22,23)$ risk of preeclampsia $(10,23)$ and high blood pressure during pregnancy (22). None of these studies distinguished between standing with and without walking, and this lack of distinction may account for the inconsistencies. A few studies used more-specific definitions for exposure. A case-control study in Quebec found frequent walking during occupational activities to be associated with a reduced risk of preeclampsia (aOR 0.61) (26). In line with this finding, a recent study from the United States reported that women with jobs involving more time standing or walking than sitting had a nonsignificantly reduced risk for preeclampsia but not for gestational hypertension (27). Interestingly, Estryn et al (21) found that long periods of standing without moving were associated with an elevated risk of preeclampsia, whereas prolonged standing alone was not; this finding is similar to our own observations. This body of literature is compatible with studies suggesting that leisure-time physical activity, which includes walking, jogging, and swimming, may be protective against preeclampsia and gestational hypertension (26-28). Unfortunately, we did not have enough details on leisure-time physical activity in this study to assess its impact on pregnancy-induced hypertension accurately.

Overall, the findings of our study and also from previous ones suggest that physical effort, such as carrying or pushing and pulling heavy loads may be deleterious. In addition, they suggest that standing per se may not be deleterious, while standing without moving may be.

In our study, as in previous ones, night work $(19,20$, $22)$, shift work $(10,23)$, high temperature $(22,23)$, and noise $(10,23)$ were not related to the risk of preeclampsia $(10,23)$ or high blood pressure during pregnancy $(19,20,22)$. Whole-body vibration and piecework or assembly-line work were slightly associated with preeclampsia in our study; this finding differs somewhat from that of two previous studies, in which no impact was found on high blood pressure during pregnancy (22) or preeclampsia (23).

Two studies from Norway reported that women who have control on their workpace and workbreaks experience a reduced risk of preeclampsia $(10,36)$. Our results were very similar, although not statistically significant. As regards job strain, our findings are consistent with 
previous observations in several aspects as well. The women with high job strain experienced a $66 \%$ increase in their risk for preeclampsia; this finding resembles the association found in previous publications reporting adjusted odds ratios ranging from $1.6(8)$ to $2.1(7,18)$. As in our study, Marcoux et al (18) found that the association with job strain was stronger for preeclampsia (aOR 2.1) than for gestational hypertension (aOR 1.3). Therefore, overall, our findings, that the lack of control on workpace (including the absence of breaks or the lack of control on the time of breaks and external pacing) and job strain increase the risk of preeclampsia are consistent with the results of previous studies.

In this study, occupational exposures were measured at the onset of pregnancy. As many as $18 \%$ of the control women benefited from a preventive withdrawal before 20 weeks of gestation. Moreover, the women without preventive withdrawal may have reduced their level of exposure through other preventive measures, such as preventive reassignments or personal arrangements with employers. This action occurred for $9 \%$ of the controls. Such preventive measures were even more frequent among those heavily exposed. Nevertheless, we could verify that at least half of the women exposed to our main occupational exposures did not have any preventive measure before 20 gestational weeks.

We found that women exposed at the onset of pregnancy are at higher risk of preeclampsia even when they benefit from preventive withdrawal before 20 weeks of gestation. In Quebec, preventive withdrawal is implemented on the basis of occupational conditions and should be independent of health status. However, it is likely that, for some women, health status influences the decision to implement a preventive withdrawal. In addition, women who are more heavily exposed may be more likely to have access to preventive withdrawal. We excluded women with chronic diseases predisposing to preeclampsia, such as chronic renal diseases. In addition, we adjusted odds ratios for risk factors of preeclampsia, such as obesity. However, residual biases leading to an underestimation of the protective effect of preventive withdrawal on the frequency of preeclampsia cannot be discarded, and this result must be interpreted cautiously.

Being exposed during early pregnancy may be sufficient for a higher risk of preeclampsia. This finding is consistent with the pathological process of preeclampsia. Although its clinical signs occur in the second half of pregnancy, the pathological process leading to preeclampsia starts early in pregnancy during the period of placentation (37). We may thus hypothesize that occupational exposures could be a trigger for preeclampsia during the period of early placentation. However, these observations were based on a limited number of persons and should be interpreted cautiously.
Our study had limitations. First, although its sample size was larger than most previous studies on the topic, it had limited power. As in most studies on the topic, occupational exposures and outcomes were self-reported retrospectively. Nevertheless, expected associations with recognized risk factors for preeclampsia and gestational hypertension were found (table 3 ). In addition, the pregnancy outcomes of the two case groups differed as expected (table 2). In our low-risk study population, we found that $2.2 \%$ of the women had preeclampsia and $2.2 \%$ had gestational hypertension. In other published population-based studies, gestational hypertension occurred in 5-8\% of all pregnant women, and preeclampsia occurred in $2-8 \%$ of all pregnant women $(2,38-42)$. The frequency found in our study is thus in the lower range of published population-based figures; this situation suggests that our study included few false positive cases. Finally, the main results could be reproduced with an alternate more-specific definition of outcome. This result provides reassurance of the validity of our outcome data. Some degree of nondifferential misclassification is likely and may have led to an underestimation of the true magnitude of the associations. Differential misclassification whereby women would report more preeclampsia and gestational hypertension and also worse work conditions cannot be excluded. It is unlikely, however, as the primary focus of the study was not on preeclampsia or gestational hypertension (32).

A "healthy worker effect" cannot be disregarded. The women who were the most heavily exposed to physical effort may be those who were better fit and at lower risk for adverse pregnancy outcome. If present, such bias would also produce an underestimation of the association between occupational physical activity and preeclampsia.

Several observations support the biological plausibility of a link between job strain or strenuous physical activity and pregnancy-induced hypertension. Preeclampsia is characterized by oxidative stress (43). Prolonged or strenuous physical exercise has been suggested to be detrimental to health through the induction of oxidative stress $(44,45)$. Strenuous exercise enhances the accumulation of secondary products of lipid peroxidation (37) and the formation of free radicals and other reactive oxygen species (45-47). A recent study compared surgery room nurses, whose work involves prolonged standing without moving, with outpatient department nurses, who can walk during their worktime (48). Interestingly, the surgery room nurses had significantly higher mean levels of reactive-oxygen-species after work. Therefore, if causal, the harmful effect of long periods of standing without walking on preeclampsia may be mediated by an elevated oxidative stress.

Preeclampsia is also characterized by decreased uteroplacental blood flow (37) and increased peripheral 
vascular resistance, which is in part mediated by overactivity sympathetic system (49). Doppler studies indicate an increase in uteroplacental vascular resistance with physical exertion (4). Both stress and strenuous physical exertion activate the sympathetic nervous system and therefore lead to the release of catecholamines and vasoconstriction, which, in turn, may have a detrimental effect on uteroplacental blood flow (50-52). Our findings that both physically demanding and stressful work conditions increase the risk of preeclampsia are in line with Hogue's hypothesis that hard physical work represents a set of acute physical stressors stimulating biophysical responses, which are similar to emotional stress (53).

In conclusion, this study suggests that occupational physical exertion, long lasting static postures, lack of control on workpace, and job strain at the onset of pregnancy increase the risk of preeclampsia.

\section{Acknowledgments}

This research was funded by the "Programme national de Recherche et de Développement en Matière de Santé de Santé Canada".

\section{References}

1. Walker JJ. Pre-eclampsia. Lancet. 2003;356:1260-5.

2. MacGillivray I, Spitz B, De Wel M, Van Assche A. Maternal mortality and morbidity in Belgium. Biol Neonate. 1989;55:30-3.

3. Chesley L. History and epidemiology of preeclampsia-eclampsia. Clin Obstet Gynecol. 1984;27:801-20.

4. Dekker G, Sibaï B. Primary, secondary and tertiary prevention of pre-eclampsia. Lancet. 2000;357:209-15.

5. Hauth JC, Ewell MG, Levine RJ, Esterlitz JR, Sibai B, Curet $\mathrm{LB}$, et al. Pregnancy outcomes in healthy nulliparas who developed hypertension: calcium for preeclampsia prevention group. Obstet Gynecol. 2000;95:24-8.

6. Eskenazi B, Fenster L, Sidney S. A multivariate analysis of risk factors for preeclampsia. JAMA. 1991;266:237-41.

7. Klonoff-Cohen HS, Cross JL, Pieper CF. Job stress and preeclampsia. Epidemiology. 1996;7:245-9.

8. Landsbergis PA, Hatch MC. Psychosocial work stress and pregnancy-induced hypertension. Epidemiology. 1996;7:34651 .

9. Higgins JR, Walshe JJ, Conroy RM, Darling MRN. The relation between maternal work, ambulatory blood pressure, and pregnancy hypertension. J Epidemiol Community Health. 2002;56:389-93.

10. Wergeland E, Strand K. Working conditions and prevalence of pre-eclampsia, Norway 1989. Int J Gynaecol Obstet. 1997;58:189-96.

11. Spinillo A, Capuzzo E, Colonna L, Piazzi G, Nicola S, Baltaro F. The effect of work activity in pregnancy on the risk of severe preeclampsia. Aust N Z J Obstet Gynaecol. 1995;35:380-5.

12. Marbury MC, Linn S, Monson RR, Wegman DH, Schoenbaum SC, Stubblefield PG, et al. Work and pregnancy. J Occup Med. 1984;26:415-21.

13. Najman JM, Morrison J, Williams GM, Andersen MJ, Keeping JD. The employment of mothers and the outcomes of their pregnancies: an Australian study. Public Health. 1989;103:189-98.

14. Jacobs DJ, Vreeburg SA, Dekker GA, Heard AR, Priest KR, Chan A. Risk factors for hypertension during pregnancy in South Australia. Aust N Z J Obstet Gynaecol. 2003;43:4218.

15. Laflamme N, Brisson C, Moisan J, Milot A, Mâsse B, Vézina M. Job strain and ambulatory blood pressure among female white-collar workers. Scand J Work Environ Health. 1998;24(5):334-43.

16. Schnall PL, Pieper C, Schwartz JE, Karasek RA, Schlussel Y, Devereux RB, et al. The relationship between 'job strain', workplace diastolic blood pressure, and left ventricular mass index: results of a case-control study. JAMA. 1990;263:1929_ 35.

17. James GD, Cates EM, Pickering TG, Laragh JH. Parity and perceived job stress elevate blood pressure in young normotensive working women. Am J Hypertens. 1989;2:637-9.

18. Marcoux S, Bérubé S, Brisson C, Mondor M. Job strain and pregnancy-induced hypertension. Epidemiology. 1999;10:37689.

19. Saurel-Cubizolles MJ, Kaminski M, Llado-Arkhipoff J, Du Mazaubrun C, Estryn-Behar M, Berthier C. Pregnancy and its outcome among hospital personnel according to occupation and working conditions. J Epidemiol Community Health. 1985;39:129-34.

20. Saurel-Cubizolles MJ, Kaminski M, Du Mazaubrun C, Llado J, Estryn-Behar M. High blood pressure during pregnancy and working conditions among hospital personnel. Eur J Obstet Gynecol Reprod Biol. 1991;40:29-34.

21. Estryn M, Kaminski M, Franc M, Fermand S, Gerstle P. Grossesse et conditions de travail en milieu hospitalier. Rev Franç Gynéc. 1978;73:625-31.

22. Saurel-Cubizolles MJ, Kaminski M, Du Mazaubrun C, Bréart G. Working conditions of women with arterial hypertension during pregnancy. Rev Epidemiol Santé Publique. 1991;39:3743.

23. Ceron-Mireles P, Harlow SD, Sanchez-Carrillo CI, Nunez RM. Risk factors for pre-eclampsia/eclampsia among working women in Mexico City. Paediatr Perinat Epidemiol. 2001;15:40-6.

24. Nurminen T, Lusa S, IImarinen J, Kurppa K. Physical work load, fetal development and course of pregnancy. Scand J Work Environ Health. 1989;15:404-14.

25. Irwin DE, Savitz DA, St Andre KA, Hertz-Picciotto I. Study of occupational risk factors for pregnancy-induced hypertension among active duty enlisted Navy personnel. Am J Ind Med. 1994;25:349-59.

26. Marcoux S, Brisson J, Fabia J. The effect of leisure time physical activity on the risk of preeclampsia and gestational hypertension. J Epidemiol Community Health. 1989;43:147-52.

27. Saftlas AF, Logsden-Sackett N, Wang W, Woolson R, Bracken MB. Work, leisure-time physical activity, and risk of preeclampsia and gestational hypertension. Am J Epidemiol 2004;160:758-65.

28. Sorensen TK, Williams MA, Lee I, Dashow EE, Thompson ML, Luthy DA. Recreational physical activity during pregnancy and risk of preeclampsia. Hypertension. 2003;41:1273-80. 
29. Higgins JR, Walshe JJ, Conroy RM, Darling MRN. The relation between maternal work, ambulatory blood pressure, and pregnancy hypertension. J Epidemiol Community Health. 2002;56:389-93.

30. Nurminen T, Kurpa K. Occupational noise exposure and course of pregnancy. Scand J Work Environ Health. 1989;15:11724.

31. Klebanoff MA, Shiono PH, Rhoads GG. Outcomes of pregnancy in a national sample of resident physicians. N Engl J Med. 1990;323:1040-5.

32. Croteau A, Marcoux S, Brisson C. Work activity in pregnancy, preventive measures and the risk of delivering a small-for-gestational-age infant. Am J Public Health. 2006;96:846-55.

33. Karasek RA. Job content questionnaire and user's guide. Los Angeles (CA): Department of Industrial and System Engeneering, University of Southern California; 1985.

34. Brisson C, Blanchette C, Guimont C, Dion G, Moisan J, Vezina M. Reliability and validity of the French version of the 18-item Karasek Job Content Questionnaire. Work Stress. 1998;12:322-36.

35. Hosmer DW, Lemeshow S. Applied Logistic regression. New York (NY): John Wiley and Sons; 1989.

36. Wergeland E, Strand K. Work pace control and pregnancy health in a population-based sample of employer women in Norway. Scand J Work Environ Health. 1998;24(3):206-12.

37. Redman CWG, Sargent IL. The pathogenesis of pre-eclampsia. Gynecol Obstet Fertil. 2001;29:518-22.

38. Vatten LJ, Skjaerven R. Is pre-eclampsia more than one disease? BJOG. 2004;111:298-302.

39. Odegard RA, Vatten LJ, Nilsen ST, Salvesen KA, Austgulen R. Risk factors and clinical manifestations of pre-eclampsia. BJOG. 2000;107:1410-6.

40. Conde-Agudelo A, Belizan JM. Risk factors for pre-eclampsia in a large cohort of Latin American and Caribbean women. BJOG. 2000;107:75-83.

41. Duley L. Pre-eclampsia and the hypertensive disorders of pregnancy. Br Med Bull. 2003;67:161-76.

42. Roberts JM, Cooper DW. Pathogenesis and genetics of pre- eclampsia. Lancet. 2001;357:53-6.

43. Wang Y, Walsh SW. Placental mitochondria as a source of oxidative stress in pre-eclampsia. Placenta. 1998;19:581-6.

44. Tozzi-Ciancarelli MG, Penco M, Massimo C. Influence of acute exercise on human platelet responsiveness: possible involvement of exercise-induced oxidative stress. Eur J Appl Physiol. 2002;86:266-72.

45. Radak Z, Kaneko T, Tahara S, Nakamoto H, Ohno H, Sasvari $\mathrm{M}$, et al. The effect of exercise training on oxidative damage of lipids, proteins, and DNA in rat skeletal muscle: evidence for beneficial outcomes. Free Radic Biol Med. 1999;27:69-74.

46. Lamprecht M, Greilberger J, Oettl K. Analytical aspects of oxidatively modified substances in sport and exercises. Nutrition. 2004;20:728-30.

47. Sen CK. Antioxidants in exercise nutrition. Sports Med. 2001;31:891-908.

48. Flore R, Gerardino L, Santoliquido A, Pola R, Flex A, Di Campli $\mathrm{C}$, et al. Enhanced oxidative stress in workers with standing occupation. Occup Environ Med. 2004;61:548-50.

49. Schobel HP, Fischer T, Heuszer K, Geiger H, Schmieder RE. Pre-eclampsia: a state of sympathetic overactivity. N Engl J Med. 1996;335:1480-5.

50. Yoshizumi M, Nakaya Y, Hibino T, Nomura M, Minakuchi K, Kitagawa $\mathrm{T}$, et al. Changes in plasma free and sulfoconjugated catecholamines before and after acute physical exercise: experimental and clinical studies. Life Sci. 1992;51:227-34.

51. Ratge D, Gehrke A, Melzner I, Wisser H. Free and conjugated catecholamines in human plasma during physical exercise. Clin Exp Pharmacol Physiol. 1986;13:543-53.

52. Hartmann S, Bung P. Physical exercise during pregnancyphysiopathological considerations and recommendations. J Perinat Med. 1999;27:204-15.

53. Hogue CJ, Hoffman S, Hatch MC. Stress and preterm delivery: a conceptual framework. Paediatr Perinat Epidemiol. 2001;15(S2):30-40.

Received for publication: 31 October 2006 


\section{Appendix}

\section{Information collected on work conditions}

\begin{tabular}{ll}
\hline Group of & Questions \\
occupational exposure &
\end{tabular}

Work schedule

Weekly workhours

Workdays per week

Unchanging or varying from week to week-average, minimum and maximum number

Daily workhours

Unchanging or varying from week to week-average, minimum and maximum number

Typical consecutive number of days without a day off

tors

Number of hours in a typical workday

Time at onset and end of a typical workday

If several schedules: time at onset and end of a workday in the other schedules

Type of schedule

Time at onset and end of breaks

Work postures

Sitting Time spent sitting during typical workday

Average time spent sitting consecutively during typical workday

$\begin{array}{ll} & \text { Possibility to stand-up when sitting for long periods of time (never or nearly never, s } \\ \text { Standing } & \text { Time spent standing (whether on the same place or walking) during typical workday }\end{array}$

Average time spent consecutively standing without sitting or having a break, during typical workday

Possibility to sit when standing (whether on the same place or walking) for long periods of time (never or nearly never,

sometimes, quite often, whenever needed)

Time spent standing at the same place during a typical workday

Time spent consecutively standing at the same place, without walking or sitting during a typical workday

Walking

Time spent walking during a typical workday

Other postures Time spent with arms above shoulder level during a typical workday

Time spent with back bent forward during a typical workday

Time spent squatting or kneeling during a typical workday

Time spent in any other uncomfortable posture-describe

Physical exertion at work

Daily frequency of pushing or pulling objects or persons during a typical workday

Daily frequency of carrying or lifting loads during a typical workday

Average weight of the load carried or lifted

Daily frequency of climbing stairs

Work organization, job strain and social support at work

Break during half-day work (never, rarely, most often, always)

Choice of the time of the break (yes, no)

Forced pace, piece work or assembly-line work (yes, no)

Items required to measure job strain through the Karasek "Job Content Questionnaire"a

French validated version of the Karasek social support scale questionnaire ${ }^{b}$

Work environment exposures

Usually, to be heard by someone at 2 meters: could speak normally, had to speak loudly or shout

Whole-body vibration (eg, from driving a vehicle or using machines with vibration), weekly hours of exposure

High temperature producing sweating in most people (never, rarely, often, always)

Low temperature obliging people to wear a coat (never, rarely, often, always)

\footnotetext{
a Reference: Karasek RA. Job content questionnaire and user's guide. Los Angeles (CA): Department of Industrial and System Engeneering, University of Southern California; 1985.

b Reference: Brisson C, Blanchette C, Guimont C, Dion G, Moisan J, Vezina M. Reliability and validity of the French version of the 18-item Karasek Job Content Questionnaire. Work Stress. 1998;12:322-36.
} 